rivlins cossider grealy exorbitant for hand which the most competent whoritios hore ralued at tas onh; in ather words, at leas than onc-third of the price given by the committes; and your memorialiote would remank further, that the ananal outlay for water (after leying the pipes, etc.) woald orentually raine the cont of the site to a much Higber price.

"Your momocialiots respectully submit that the objection igned bove are velid, whetber considered with reopect to the future well being of the cotablishment, on in reapect to the feelings and interents of your memorialiots and the ratepayers of the county at large.

" Your memorialists are of opinion that for the comfort and well-being of the poor unfortunato parsons who are to beeome the inmates of the asylum, it is requisite above all things to have a plentiful expply of good water, a genial atmoophere, and a salnbrious locality, as very poesible, where the landecape is raried and picturesque the contemplation of which may be a source of daily pleasure to the unhappy lunatic, and may tend to arraken new emotion and create wider aympathies in his bowom, and thrs materially condace to bis restoration; and your memorialints pledge themselves that several such sites may bo obtained in convenient localities in this conenty.

"Your memorialists therefore humbly pray that your honourable Board will withhold your approval of the said proposed sita."

A similar memorial will be forwarded to Lord Palmernton, the Home Souretary.

It is stented that this memorial has been signed by the great bulk of the tradeomen and ratepayers of the city of Carlisle, and the towns and districts of the connty; and it is a signiflcant fact, that the medical men of Carlisle to the number of fourtoen have signed a similar petition. "The Baards of Guardians have also taken ap the question in a most earnest and recolute spirit." Unfortunately, Mr. Grainger, who was sent by the Commissioners in Lunacy for that purpose, has examined the site, and has approved of it. The statements in the memorial appear to be more than efficient why that approval should be rocontiderod.

\section{To the Editor of the Asylum Journal.}

Sis,-During the debate in the House of Commons on the 28th of Fobruary last on a motion for a Contmittee of Enquiry on Nunneries, Mr. T. Chambers, the mover, refarred to the insanity of Miss Knight in the nunnery at Taunton, in the following words: "The house would probably remember that considersble attention was called to a case at Tanton, in which Miss Knight, a convert, had had the misfortune to loso her sences, and notwithstanding the consent of the bishop had been obtained, Miss Jerningham, the lady superioress, wonld not suffer a Roman Catholic doctor to visit har, would not suffer her to go to Bristol, even to a convent there, but against the wishes and consent of her brother, detarmined to take her abroad to die in Belgium; and it was only by tho most strenuous

- It wer problasod tor sas per acro threo jears ago. exertions that her brother succeeded, amid the jeers and ineults of the priest, in getting ber away, and sho died in this contry. Surely if they wanted an instanee of despotic power, that was one."

As this case presents ceveral pointe of interest to the mental pathologint, I beg to offer you some remarks apon it, for ineertion in the Angiem Jownal At the same time I shall correct tro important errors in Mr. Chambers's otatement, and sroid as much es possible any political or religious bien.

In the first place, Mr. Chambers was wrong in theting Mise Knight to be a convert. So far was this from being the case, that her father, a Romean Cathalic gentleman of Deronshire, hed always educated her in his own faich. Her want was a vistor in tho Taunton nannery, and hor threo sioters had been educsted in the same religious honse.

Becondly, Mr. Chmbers was wrong in stating, that the lady saperioress would not wuffer a Roman Catholic doctor to visit the patient. Dr. O'Bryen, the Roman Catholic physician to St. Peter's Hospital for the Insane at Bristol, did visit Mies Kright at the convent, and pronounced it as his opinion that a cure coald be effected if the was removed to Clifton and pleced under his treatment.

The points of medical interest in this melancholy case are three: the duration of the insenity, the power of detaining an insane person in a nunnery without reference to the Commissioners in Lanacy, and the homoopathic treatment of insanity adopted by the lady superioress.

The relatives of the unfortunate lady and ber religions superiors differ in their opinion respecting the the cause and the duration of her insanity. The confessors and the lady superioress of the convent affirm, that they had been awrare of the existence of mental disease for a period of six years before an outbreak of violence had rendered it nocesesury to make the fact known to her relations. During this long period she had been the victim of various insane delusions; in the spring of last year the tranquillity of demeanor which she had hitherto retained, passed into a stato of maniacal excitament. The childron going to the convent school were obliged to be sent by an unusual way to aroid hor cries; tho poor patient became unmanageable, and it was necessary that the quietude of the convent should be restored by her removal. Her aged parents and her brother wore now informed of the calamity, and of the intention of the lady superioress to remove her to the convent of Menin in Belgium, an establishment devoted to the reception of insane nuns. The relations felt great repugaance to concur in this act of departation, and arged that the patient should be placed in a convent near Bristal, under the medical care of Dr. O'Bryen, a Catholic physician well skilled in the trewtment of mental disorders, and a friend of the family. To this request, spparently so reasonsble, the lady superioress made the most strenuous opposition, an opposition which can only be understood by remombering, that the physiaian and the lady bolding the same faith in raligion, entertained rival creeds in medicine. The lady superioress was a fanatical sectarian of the Hannehman faith, and her conduct in opposing Dr. O'Bryen 
must be riewed by the light of this fact. The Catholic bishop of Cliton added his entreaties to thowe of Miss Knight's relative for her removal to Bristol: a circumstance beaving no doubt that Miss Jerningham's opposition was actrated not so moch by raligions scraples as by indignation at her "outraged homooopathy."

Miss Knight was overtnally removed, bet after so protracted a delay, that sho mbeoguently lived only throe weeks

Is it not reaconable to sropose, that if this unhappy lady had met with proper treatment at the earlior stage of bar diseace, her mind might have been rostored and her life presarved?

Finally, let me ask, what would bo the power of the Commisoioners in Lunacy in a similar case? By the eighth section of the Act for the Regulation of the Cere and Treatment of Lumatica, no single pattent can be taken charge of in a ptivate house without proper certificates sent to the Commisioners, and without offeiel visitation. Would this enactment affect insane patient in a convent, or would the character of the house interpose a bar between the Commissioners and their daties? If 80 , would the same occur in the instance of any other religions community, an Anglican sisterhood, for example, or an Agapemone? Should this be the case, and should any person wish to establish a perfectly close uninspected asylum for ladies, it will only be nocessary to give it the character of a religious community, and to defy the law and the Commissioners.

In the present instanco the pationt was insane six years before her relations know it, and was treated homoeopathically; she appears in other rezpects to have received personal kindness and humane attention at the hands of her superior. Is it impossible that in other places both the globules and the humanity may be conitted, and the old syatem of trating the insane in convents and monasteries described by Fequirol should be resartod to?

I am, Sir, your obedient sorvant,

M. D.

London, March \$rd, 1854.

\section{Statistics of the Insane in France.}

A report on the situation of lunatic in the asylums of Paris was presented to the conncil general of the Seine in its last sessiton. On the 31 st December, 1852, the number of lunatics under treatment was 3182. In all France there were 16,719 , which made one in every 2128 of the total population; but in Paris and the department of the Seine the proportion was one in every 474. This was owing to the fact, that at Paris idiots are readily admittod into asylums, in order to prevent them from becoming a spectacle or being illtreated in the streets; whereas, in the country, great numbers not being dangerous are allowed to be at large, and are generally treated kindly by everybody. In 81 yeara the number of lanatics in Paris and the department of the Soine has increasod from 946 to 3182. The number of admissions in the coures of 1852 was 1509. Amongst them were 454 tradere, 149 members of liberal profescions, 26 agriculturists, etc.;
976 of them belonged to Paris, 182 to tho department of the Seine, the rest to different parts of France, and 61 to foreign conntries Amongat the forvigners were 1 Englishman, 21 Belgians, 16 Sardinians, 6 Prussiong, and 5 Garmans. The unmber of poreons diseharged in the course of the year was 849; of cared, 556; and of deathe, 462. The proportion of deathes was neerily half less then in the ordinary hospitals; and the pripcipal canse of them was paralysis, that dicease haring caused 194 of the total. All the lonatics of Paris and the department are not treated in the agylumis of Parios somo are maintained in those of tho provinces-Bloia, Marévillo (Muertho), Amentières (Nord), etc--but at the expense of Paris. The expense of each lunatio per day in Paris was If. BOc. for mon, and $1 \mathrm{f} .20 \mathrm{a}$ for women; and in the prorinces it areraged from If. to If. $25 \mathrm{c}$. The total expense of the year was $1,438,432 \mathrm{f}$. 78 c.; of which $464,065 \mathrm{f}$. were disbumed in the arylum of Bicêtre, 592,542f, in that of Ia Sal. petrière, and the rest in the provinces. Part of the expense, however, has to be repaid by the families of the pationts, the prefecture of police, and the rural communes; and another part by foraign governments -amonget which govermments that of Fingland anes 711f. S0c; that of Belgium, 6344f. 50 c.; and that of Piedmant, $2867 \mathrm{f} .80 \mathrm{c}$. By a law of 1838, two socts of admistion into lunatic esylums are allowed: one, called "voluntary," is that of non-dengerons Innatice on the demand of thair families; the second, called "official," is ordered by the prefecture of police, with respect to persons whose maladies are dangerous to themselves or others. Before 1838 the number of offcial admissions was less than that of voluntary admissions; from 1833 to 1838 , for example, the former was 2821, and the latter 4242. But from 1838 to 1851 , out of 16,716 admissions, 4163 were voluntary and 12,553 official. Of the 1509 admissions of 1852, 398 were voluntary and 1111 official. Up to the commencement of the nineteenth centary, the laws did not occupy themselves with the condition of Innatics. Confounded with thieves and vagabonde, lunatice ware confined in the prisons and hospitale. From a report presented in 1791 to the National Assembly by M. do Ls Rochefoucald-Liencourt, it appoars that at that time the number of lnatics was 1831. At that period two wards of the Hôtel-Dieu were recorved to the curable; but they were often pleced three or four together, men and women in the name bed; the mare violent were even bound with chains, and the oher patients beard all day long their cries, or witneseced painful scenes. The incurables were placed at Bicetre, Ia Selpetrière, and the Petites-Mtaions (at present Hoopice des Méneages). The cells in which they were confined were only six feet square; light and air were admitted by the door; trucklo beds, covered with straw and fastened to the walls, ware all they had to sleep on; and water fell from the walls. In 1792, Dr. Pinel, physicim of Bictres, and afterwands of Ia Salpétrière, put an and to this frightfal state of thingt The creation of the Comoil Genasal des Hoepices in 1800 completed his undartaking. Sinos that time rast improvements have been introduced into the treatment of the insene. Spacions and healthy lodgings with boerded floor have been substituted for 